\title{
Gambaran pemeriksaan gigi untuk identifikasi korban meninggal di Bagian Kedokteran Forensik dan Medikolegal RSUP Prof. Dr. R. D. Kandou Manado tahun 2010 - 2015
}

\author{
${ }^{1}$ Cornelius F. Tandaju \\ ${ }^{2}$ James Siwu \\ ${ }^{3}$ Bernart S. P. Hutagalung
}

\author{
${ }^{1}$ Kandidat Skripsi Program Studi Pendidikan Dokter Gigi Fakultas Kedokteran \\ ${ }^{2}$ Bagian Ilmu Kedokteran Forensik \& Medikolegal Fakultas Kedokteran \\ ${ }^{3}$ Program Studi Pendidikan Dokter Gigi Fakultas Kedokteran \\ Universitas Sam Ratulangi Manado \\ Email: fredeman.tandaju@ yahoo.com
}

\begin{abstract}
Recently, there were many disasters that led to large numbers of human victims. Identification is important not only to analyze the cause of death, but also to provide psychological tranquility for the families with certainty of the victim identity. Tooth is resistant to high temperature due to its less organic tissue, therefore, it is very helpful in the identification of the victim on fire. Dental examination is an accurate and easily done method for the identification of a dead victim. This study was aimed to obtain the profile of dental examination in the identification of the dead victims at the Forensic and Medicolegal Department, Prof. Dr. R. D. Kandou Hospital Manado, from 2010 through 2015. This was a retrospective study. The result showed that there were 378 deaths in that period. There were 8 dead victims with dental examination; one of them had no identity. Conclusion: Most dead victims with dental examination at Prof. Dr. R. D. Kandou Hospital Manado had their identities.
\end{abstract}

Keywords: identification of dead bodies, tooth examination

\begin{abstract}
Abstrak: Beberapa tahun terakhir ini banyak kejadian bencana yang menyebabkan jumlah korban manusia yang besar. Proses identifikasi menjadi penting bukan hanya untuk menganalisis penyebab suatu kematian, namun juga upaya untuk memberikan ketenangan psikologis pada keluarga dengan adanya kepastian identitas korban. Gigi memiliki ketahanan terhadap temperatur yang tinggi sehingga sangat bermanfaat dalam identifikasi pada korban terbakar. Hal ini disebabkan sedikitnya jaringan organik yang dikandungnya. Pemeriksaan gigi dalam pengenalan jenazah merupakan metode yang akurat dan mudah dilakukan. Penelitian ini bertujuan untuk mengetahui gambaran pemeriksaan gigi untuk identifikasi korban meninggal di Bagian Kedokteran Forensik dan Medikolegal RSUP Prof. Dr. R. D. Kandou Manado periode tahun 2010-2015. Jenis penelitian ini ialah retrospektif. Hasil penelitian mendapatkan data 378 korban meninggal yang masuk di Bagian Kedokteran Forensik dan Medikolegal RSUP Prof. Dr. R. D. Kandou Manado pada tahun 2010-2015. Terdapat 8 korban meninggal dengan pemeriksaan gigi; 1 korban tidak memiliki identitas. Simpulan: Sebagian besar korban meninggal dengan pemeriksaan gigi di RSUP Prof. Dr. R. D. Kandou Manado memiliki identitas.
\end{abstract}

Kata kunci: identifikasi jenazah, pemeriksaan gigi 
Beberapa tahun terakhir ini banyak kejadian bencana yang menyebabkan jumlah korban manusia yang besar. Penyebab bencana bermacam-macam, yakni akibat ulah manusia (bencana bom, kebakaran), bencana alam (banjir, longsor, gunung meletus), kecelakaan transportasi (darat, laut, udara) dan lain-lain. Pada kejadian tersebut terdapat korban yang sulit untuk dikenali karena tidak adanya tanda pengenal. Setiap orang mempunyai identitas untuk membedakannya dari orang lain. Sesuai dengan data yang ada, maka pada tahun 2009 terdapat sekitar 3000 kematian yang terjadi di Kota Manado, dan itu bukanlah suatu jumlah yang sedikit. ${ }^{1,2}$

Proses identifikasi menjadi penting bukan hanya untuk menganalisis penyebab suatu kematian, namun juga upaya untuk memberikan ketenangan psikologis pada keluarga dengan adanya kepastian identitas korban. Identifikasi merupakan penentuan atau penetapan identitas orang hidup atau mati, berdasarkan ciri-ciri yang khas yang terdapat pada orang tersebut. ${ }^{3}$

Identitas individu mempunyai aspek hukum, sebagai contoh orang meninggal akibat tindakan kriminal harus ditentukan identitasnya untuk keperluan dalam penegakan hukum. Pasal 118 ayat (1) undang-undang no. 36 tahun 2009 tentang kesehatan, mayat yang tidak dikenal harus dilakukan upaya identifikasi. Terdapat beberapa metode identifikasi yang dilakukan, antara lain pengenalan visual, pengenalan barang milik pribadi, sidik jari, karakteristik gigi hingga DNA. Di antara metode-metode tersebut, DNA, karakteristik gigi, metode sidik jari mempunyai validitas individu yang tinggi. ${ }^{4}$ Manusia, memiliki 32 gigi dengan bentuk yang jelas dengan demikian di dalam rongga mulut terdapat berbagai variasi keadaan gigi yaitu baik rusak, ditambal, dicabut, gigi tiruan, implant, dan lain-lain.

Gigi memiliki ketahanan terhadap temperatur yang tinggi sehingga sangat bermanfaat dalam identifikasi pada korban terbakar. Hal ini disebabkan sedikitnya jaringan organik yang dikandungnya.
Pemeriksaan gigi dalam pengenalan jenazah merupakan metode yang akurat dan mudah dilakukan sebab alasan yang dikemukakan mengapa gigi dapat dipakai sebagai sarana identifikasi yaitu karena gigi merupakan bagian terkeras dari tubuh manusia. ${ }^{5,6}$

Ilmu forensik (biasa disingkat forensik) merupakan sebuah penerapan dari berbagai ilmu pengetahuan untuk menjawab pertanyaan-pertanyaan yang penting untuk sebuah sistem hukum yang mana hal ini mungkin terkait dengan tindak pidana. Namun disamping keterkaitannya dengan sistem hukum, forensik umumnya lebih meliputi sesuatu atau metode-metode yang bersifat ilmiah dan juga aturan-aturan yang dibentuk dari fakta-fakta berbagai kejadian, untuk melakukan pengenalan terhadap buktibukti fisik (contohnya mayat, bangkai, dan sebagainya).

Penelitian ini bertujuan untuk mendapatkan gambaran pemeriksaan gigi untuk identifikasi korban meninggal yang dilakukan di Bagian forensik dan medikolegal RSUP Prof. Dr. R. D Kandou Manado.

\section{METODE PENELITIAN}

Jenis penelitian yang dilakukan ialah deskriptif retrospektif. Penelitian ini dilaksanakan di Bagian Forensik dan Medikolegal RSUP Prof. Dr. R. D. Kandou Manado pada bulan Oktober 2016. Populasi penelitian ialah korban meninggal yang terjadi di Sulawesi Utara pada tahun 2010-2015 yang diperiksa di Bagian Kedokteran Forensik dan Medikolegal RSUP Prof. Dr. R. D. Kandou Manado. Sampel yang di ambil ialah seluruh kasus korban meninggal tahun 2010-2015 yang diperiksa di Bagian Kedokteran Forensik dan Medikolegal RSUP Prof. Dr. R. D. Kandou Manado. Pengumpulan data secara retrospektif dari data di Bagian Kedokteran Forensik dan Medikolegal RSUP Prof. Dr. R. D. Kandou Manado tahun 20102015.

Pengolahan data dilakukan secara manual dan komputerisasi dan disajikan 
dalam bentuk tabel dan persentase yang mencakup :

1. Jumlah kasus korban meninggal sesuai data di Bagian Kedokteran Forensik dan Medikolegal RSUP Prof. Dr. R. D. Kandou Manado tahun 2010-2015.

2. Jumlah korban meninggal dengan pemeriksaan gigi sesuai data di Bagian Kedokteran Forensik dan Medikolegal RSUP Prof. Dr. R. D. Kandou Manado tahun 2010-2015.

\section{HASIL PENELITIAN}

Tabel 1 memperlihatkan data korban meninggal tahun 2010-2015 di Bagian Kedokteran Forensik dan Medikolegal RSUP Prof. Dr. R. D. Kandou Manado. Pada tahun 2010 didapatkan 50 data korban meninggal (13,23\%); pada tahun 2011 didapatkan 11 data korban meninggal (2,91\%); pada tahun 2012 didapatkan 58 data korban meninggal (15,34\%); pada tahun 2013 didapatkan 68 data korban meninggal $(17,99 \%)$, pada tahun 2014 didapatkan 77 data korban meninggal (20,37\%); dan pada tahun 2015 didapatkan 114 data korban meninggal $(30,16 \%)$.

Tabel 1. Jumlah kasus korban meninggal yang diperiksa di Bagian Kedokteran Forensik dan Medikolegal RSUP Prof. Dr. R. D. Kandou Manado tahun 2010-2015

\begin{tabular}{ccc}
\hline Tahun & Jumlah data & \% \\
\hline 2010 & 50 & 13,23 \\
2011 & 11 & 2,91 \\
2012 & 58 & 15,34 \\
2013 & 68 & 17,99 \\
2014 & 77 & 20,37 \\
2015 & 114 & 30,16 \\
Total & 378 & 100 \\
\hline
\end{tabular}

Berdasarkan Tabel 2 dapat dilihat pada tahun 2010-2015 didapatkan 8 korban meninggal yang diperiksa di Bagian Kedokteran Forensik dan Medikolegal RSUP Prof. Dr. R. D. Kandou Manado dengan pemeriksaan gigi. Pada tahun 2010 dan 2011 masing-masing terdapat 2 korban meninggal dengan pemeriksaan gigi (25,00\%); pada tahun 2012 dan 2014 di
Manado terdapat masing-masing 1 korban meninggal dengan pemeriksaan gigi (12,50\%); dan pada tahun 2015 terdapat 2 korban meninggal dengan pemeriksaan gigi $(25,00 \%)$. Pada tahun 2013 tidak terdapat korban meninggal dengan pemeriksaan gigi.

Tabel 2. Jumlah pemeriksaan gigi pada jenazah di Bagian Kedokteran Forensik dan Medikolegal RSUP Prof. Dr. R. D. Kandou Manado tahun 2010-2015

\begin{tabular}{ccc}
\hline Tahun & Jumlah data & \% \\
\hline 2010 & 2 & 25 \\
2011 & 2 & 25 \\
2012 & 1 & 12,5 \\
2013 & 0 & 0 \\
2014 & 1 & 12,5 \\
2015 & 2 & 25 \\
\hline
\end{tabular}

Berdasarkan Tabel 3 dapat dilihat pada tahun 2010-2015 terdapat 1 korban meninggal tanpa identitas yang diperiksa di Bagian Kedokteran Forensik dan Medikolegal RSUP Prof. Dr. R. D Kandou Manado tanpa identitas. Pada tahun 2010, 2011, 2012, 2013, dan 2014 tidak terdapat korban meninggal dengan tanpa identitas. Pada tahun 2015 terdapat 1 korban dengan pemeriksaan tanpa identitas.

Tabel 3. Jumlah kasus korban meninggal tanpa identitas yang masuk di Bagian Kedokteran Forensik dan Medikolegal RSUP Prof. Dr. R. D. Kandou Manado tahun 2010-2015

\begin{tabular}{ccc}
\hline Tahun & Jumlah data & $\%$ \\
\hline 2010 & 0 & 0 \\
2011 & 0 & 0 \\
2012 & 0 & 0 \\
2013 & 0 & 0 \\
2014 & 0 & 0 \\
2015 & 1 & 100 \\
Total & 1 & 100 \\
\hline
\end{tabular}

\section{BAHASAN}

Hasil penelitian ini mendapatkan data sebanyak 378 korban meninggal pada tahun 2010-2015 yang masuk di Bagian Kedokteran Forensik dan Medikolegal 
RSUP Prof. Dr. R. D. Kandou Manado. Dari sejumlah kasus tersebut, terdapat 8 korban dengan pemeriksaan gigi, 1 korban dengan pemeriksaan tanpa identitas. Hal ini disebabkan karena tidak lengkapnya data sedangkan pada peraturan Menteri Kesehatan no. 269 tahun 2008 tentang penyimpanan rekam medis disebutkan bahwa rekam medis di rumah sakit wajib disimpan sekurang-kurangnya untuk jangka waktu 5 tahun, dan setelah batas 5 tahun rekam medis dapat dimusnahkan. Data penelitian sebelumnya mendapatkan pada tahun 2010 terdapat 161 data dan pada tahun 2011 terdapat 189 data di Bagian Kedokteran Forensik dan Medikolegal RSUP Prof. Dr. R. D. Kandou Manado. ${ }^{7}$

Hal ini yang menjadi salah satu kendala bagi peneliti untuk mendapatkan data yang lengkap mengenai data pemeriksaan korban meninggal yang diperiksa di Bagian Kedokteran Forensik dan Medikolegal RSUP Prof. Dr. R. D. Kandou Manado. Dalam hal kasus seperti kecelakaan lalu lintas, kecelakaan kerja, penganiayaan, maupun korban pembunuhan, jarang dilakukan pemeriksaan gigi terhadap korban, karena pada setiap kasus pasti sudah dapat dilihat pola luka yang ada sehingga tidak perlu dilakukan pemeriksaan yang lebih menyeluruh.

\section{SIMPULAN}

Dari hasil penelitian di Bagian Kedokteran Forensik dan Medikolegal RSUP Prof. Dr. R. D. Kandou Manado dapat disimpulkan bahwa pada tahun 20102015 sebagian besar korban meninggal dengan pemeriksaan gigi memiliki identitas.

\section{SARAN}

Pada pemeriksaan jenazah sebaiknya dilengkapi dengan pemeriksaan gigi karena berpeluang dibutuhkan untuk suatu kasus dalam pengadilan. Penyimpanan berkas data perlu diperhatikan mengingat RSUP Prof. Dr. R. D. Kandou Manado merupakan rumah sakit pendidikan.

\section{DAFTAR PUSTAKA}

1. Poluan HHR, Kristanto E, Wowor VNS. Gambaran data odontogram rekam medik gigi di balai pengobatan Rumah Sakit Gigi dan Mulut Universitas Sam Ratulangi Manado. eG. 2013;1(2).

2. Kambey GSAY, Tomuka D, Mallo JF. Aspek medikolegal tatalaksana kematian di Kota Manado. eBm. 2013;1(1):111-7.

3. Siwu TL, Tomuka D, Mallo NTS. Peran dokter di tempat kejadian perkara di Manado. eCl. 2015;3(1).

4. Sutra D. Fungsi kepolisian sebagai penyidik utama: studi identifikasi sidik jari dalam kasus pidana. Jurisprudence. 2012;1(1):74-88.

5. Budi AT. Peran restorasi gigi dalam proses identifikasi korban. Jurnal PDGI. 2014;63(2)41-5.

6. Syafitri K, Auerkari E, Suharono W. Pemeriksaan jenis kelamin melalui analisis histologis dan DNA dalam identifikasi odontologi forensik Jurnal PDGI. 2013;62(1:11-6).

7. Rorora JD, Tomuka D, Siwu J. Temuan otopsi pada kematian mendadak akibat penyakit jantung di BLU RSU Prof. Dr. R.D. Kandou Manado periode 20072011. eCl. 2014;2(3). 